\title{
Oblikovanje nove finančne perspektive EU in pogajalska izhodišča Slovenije
}

UDK: $339.7(497.4)$

Aleksander Aristovnik

Univerza v Ljubljani, Fakulteta za upravo

aleksander.aristovnik@fu.uni-lj.si

\section{IZVLEČEK}

Oblikovanje nove finančne perspektive Evropske unije (EU), tj. srednjeročnega strateškega javnofinančnega načrta za obdobje 2007-2013, predstavlja po sprejemu ustavne pogodbe junija 2004 nov velik izziv razširjene EU. To dokazujejo že sami začetki pogajanj o vsebinskih in tehničnih podrobnostih nove finančne perspektive med najpomembnejšimi evropskimi institucijami in državami članicami EU, med njimi tudi Slovenijo, kjer so razvidne velike razlike med posameznimi pogajalskimi izhodišči. V okviru pogajanj se Slovenija zavzema, da bi prilagojena struktura naslednje finančne perspektive čim bolje odražala sedanje ključne vsebinske cilje razširjene EU (npr. cilje lizbonske strategije). Zato Slovenija zagovarja ohranitev reformirane kohezijske politike kot temeljnega instrumenta uresničevanja načela solidarnosti, nadaljnjega prestrukturiranja sredstev za Skupno kmetijsko politiko (SKP) v smeri pridelave zdrave hrane, zaščite zdravja ljudi in razvoja podeželja, in povečanja sredstev namenjenih krepitvi vloge EU kot globalnega partnerja ter izgraditve EU kot območja svobode, varnosti in pravičnosti. Za uresničitev omenjenih ciljev Slovenija podpira predlog Evropske komisije, po katerem je za potrebe prihodnje finančne perspektive predvideno v povprečju 1,14 odstotka bruto nacionalnega dohodka (BND). Na strani finančnih virov Slovenija zagovarja postopno opuščanje vira na osnovi DDV ter nasprotuje uvedbi t. i. evropskega davka. Ob uresničitvi predhodno navedenih stališč lahko Slovenija v okviru prihodnje finančne perspektive poleg ugodnega neto finančnega položaja pričakuje tudi pospešeno dinamiko gospodarskega razvoja znotraj (gospodarsko in politično) najrazvitejše integracije na svetu.

Ključne besede: EU, nova finančna perspektiva, širitev EU, trajnostni razvoj, evropski model družbe, vloga EU v svetu, Slovenija

\section{Predlog prihodnje finančne perspektive EU 2007-2013}

Evropska komisija je v Sporočilu (angl. Communication from the Commission to the Council and the European Parliament) v začetku leta 2004 predstavila predlog prihodnje finančne perspektive 2007-2013, ki odseva njene poglede na naslednje 


\section{Aleksander Aristovnik \\ Oblikovanje finančne perspektive EU in pogajalska izhodišča Slovenije}

finančno obdobje. Pristop oblikovanja finančne perspektive je podoben kot pri prejšnjih perspektivah. Evropska komisija najprej identificira glavne cilje $v$ naslednjem obdobju, ki jih nato ob upoštevanju mehanizmov implementacije ustrezno ovrednoti.

Glavni strateški cilji EU bolj ali manj temeljijo na ugotovitvah "Sapirjevega poročila «", kjer se izpostavlja prestrukturiranje proračunskih sredstev EU v smeri izpolnjevanja ciljev lizbonske strategije in bistvenega zmanjšanja sredstev, namenjenih kmetijstvu. Več nejasnosti je na strani mehanizmov implementacije politik za dosego zastavljenih ciljev. Sapirjevo poročilo na primer ugotavlja, da obstaja nesoglasje znotraj EU glede (nacionalne ali nadnacionalne) ravni implementacije posameznih politik (npr. kmetijske in kohezijske politike). Na nejasnost implementacije opozarja tudi Mayhew (2004), ki izpostavlja problem izdatkov za raziskave in razvoj $(R \& R)$ EU, katerih učinki se $v$ preteklosti $v$ primerjavi z nacionalnimi izdatki niso izkazali za bolj uspešne oz. učinkovite. Podobne nejasnosti glede implementacije posameznih politik se kažejo tudi na področju uresničevanja ideje "en instrument za posamezno politiko, en sklad za posamezni program «, kjer se po eni strani res predvideva združevanje in konsolidacija obstoječih skladov (npr. strukturni skladi, predpristopni instrumenti ipd.), hkrati pa je predvideno oblikovanje novih skladov (npr. Sklad za prilagajanje rasti).

Tudi postopek sprejemanja nove finančne perspektive bo $v$ skladu $s$ tradicijo potekal $\vee$ dveh predvidenih stopnjah. $\vee$ prvi stopnji naj bi bil dosežen politični dogovor o razdelitvi finančnih sredstev, $v$ naslednji pa naj bi bili sprejeti še vsi zakonodajni predlogi, ki bodo dogovor uresničili in predstavljali pravno podlago za izvajanje prihodnje finančne perspektive. Tako je Evropska komisija julija 2004 ob upoštevanju odzivov na predlog že predstavila paket finančnih in zakonodajnih predlogov, vezanih na naslednjo finančno perspektivo (European Commission, 2004d). $\checkmark$ njem Evropska komisija dopolnjuje in udejanja predloge usmeritev, predstavljene $v$ Sporočilu februarja 2004. Vendar pa je do dokončnega političnega dogovora glede naslednje finančne perspektive še daleč, saj naj bi bil v najboljšem primeru dosežen junija 2005 na zasedanju Evropskega sveta (predvidoma v Luksemburgu) (Council of the European Union, 2004).

$\checkmark$ nadaljevanju si najprej oglejmo tri ključne politične prioritete prihodnjega razvoja EU, ki hkrati pomenijo temelj predloga razporeditve izdatkov $\vee$ okviru prihodnje finančne perspektive EU.

1 Podrobneje glej Sapir et al., 2003. 


\section{Aleksander Aristovnik \\ Oblikovanje finančne perspektive EU in pogajalska izhodišča Slovenije}

\subsection{Glavne prioritete prihodnje finančne perspektive EU}

I) Trajnostni razvoj - spodbujanje rasti, kohezije in zaposlenosti

Na srečanju Evropskega sveta v Lizboni leta 2000 so predsedniki držav in vlad članic EU soglašali s programom, ki naj bi EU pripeljal na mesto "najbolj dinamičnega, konkurenčnega in trajnostno na znanju temelječega gospodarstva na svetu, ki bo uživalo polno zaposlenost ter ekonomsko in socialno kohezijo«. Kasneje, na goeteborškem vrhu leta 2001, je bila lizbonska strategija dopolnjena z usmeritvami na področju okolja, tako da sedaj tvori celovito strategijo trajnostnega razvoja EU. Za dosego postavljenih ciljev strategije bo morala EU pospešiti naložbe na ključnih področjih razvoja, kot so naložbe $v$ povečevanje konkurenčnosti podjetniškega sektorja na notranjem trgu, naložbe $v$ R\&R, povezovanje EU na osnovi mreženja, izboljšanje kakovosti izobraževanja in usposabljanja ter zagotavljanje obvladovanja socialnih sprememb v družbi.

Pomemben cilj prihodnjega razvoja razširjene EU je tudi zagotavljanje enakomernega razvoja celotnega območja, s posebnim poudarkom na zmanjševanju socialno-ekonomskih razlik med regijami. Tako se je s širitvijo EU razmerje med desetimi odstotki najbolje razvitih regij in desetimi odstotki najslabše razvitih regij $v$ integraciji povečalo z 2,6 na 4,4 (EU Regional Policy, 2004). Pri zmanjševanju teh razlik bo ključno vlogo odigrala reforma kohezijske politike, ki je nujna tako z vidika učinkovitega izvajanja kot tudi financiranja politike $v$ razširjeni EU po letu 2006. Reformirana kohezijska politika naj bi še vedno temeljila na identičnih osnovnih načelih (ciljna usmerjenost, koncentracija, dodajanje sredstev, programiranje, partnerstvo in usklajevanje, finančna kontrola, spremljanje, evalvacija), prinaša pa spremembe glede večjega ciljnega usmerjanja dejavnosti, poenostavitve in transparentnosti. $\vee$ tej povezavi naj bi se število prioritet oz. ciljev kohezijske politike zmanjšalo z devet na tri (tj. konvergenca in konkurenčnost, regionalna konkurenčnost in zaposlovanje ter teritorialno sodelovanje). Podobna poenostavitev se pričakuje tudi na področju finančnih instrumentov, kjer naj bi od obstoječih petih ostali le še trije, in sicer Evropski sklad za regionalni razvoj (ESRR), Evropski socialni sklad (ESS) in Kohezijski sklad (European Commission, 2004c).

Reorganizacija finančnih instrumentov se dotika tudi skupne kmetijske politike (SKP) EU, saj se bosta kmetijski in ribiški sklad (usmerjevalni oddelek Evropskega kmetijskega usmerjevalnega in jamstvenega sklada (EKUJS) in Finančni instrument za usmerjanje ribištva (FIUR)) preoblikovala $v$ enotni instrument SKP. Vendar pa je to le ena od vrste dejavnosti, povezanih z uveljavitvijo v letu 2003 sprejete reforme SKP. Reforma SKP naj bi temeljito preusmerila njene cilje delovanja $k$ trajnostnemu razvoju in odpravi subvencioniranja proizvodnje. Tako naj bi se sproščena sredstva iz naslova predvidenega zmanjšanja neposrednih plačil, vezanih na obseg proizvodnje, preusmerila k razvoju podeželja (European Commission, 2004a). Že zdaj je 


\section{Aleksander Aristovnik \\ Oblikovanje finančne perspektive EU in pogajalska izhodišča Slovenije}

posebna pozornost namenjena celostnemu razvoju visokogorskih kmetij in podeželja, prenovljena kmetijska politika pa bo še bolj osredotočena na spodbujanje dopolnilnih kmetijskih dejavnosti, izboljševanju kakovosti, krepitvi konkurenčnosti kmetijstva, zagotavljanju varstva okolja in varovanju zdravja živali.

II) Evropski model družbe - svoboda, varnost in pravičnost

Svoboda, varnost in pravičnost so ključne sestavine evropskega modela družbe. To je potrdilo tudi srečanje Evropskega sveta $\vee$ Tampere (Finska) leta 1999, kjer so se države članice zedinile o natančnem načrtu oblikovanja območja svobode, varnosti in pravičnosti. Načrt vključuje tudi prenos večine pristojnosti na tem področju z nacionalne ravni na raven EU, kar omogoča lažje reševanje problemov, kot so priseljevanje in vključevanje zakonitih priseljencev, ilegalne migracije, organiziran kriminal in terorizem. Podobno velja tudi za probleme, povezane z naravnimi nesrečami, zdravstvenimi in okoljskimi kriznimi žarišči, dostopom do javnih storitev itd.

\section{III) Krepitev vloge EU v svetu}

$Z$ več kot 450 milijoni prebivalstva in okoli četrtino svetovne proizvodnje bi morala razširjena EU imeti večji politični in gospodarski vpliv na blaginjo in stabilnost tako $v$ Evropi kot $v$ svetu. Tudi države članice EU soglašajo, da se mora vloga razširjene EU povečati tako $v$ regionalnem kot tudi $\vee$ globalnem smislu. $\vee$ regionalnem smislu mora EU poleg zagotavljanja stabilnosti znotraj EU poskrbeti za stabilnost tudi $\vee$ sosednjih državah/regijah. Krepitev mednarodne trgovine in naložb, spodbujanje regulacijske konvergence, prepletanje prometnih, energijskih in komunikacijskih mrež EU s soseščino zagotavlja koristi za vse vpletene strani. V globalnem smislu pa mora EU okrepiti svojo vlogo na področju globalnega političnega sodelovanja in strateške varnosti. To vključuje tudi boj proti različnim oblikam groženj (npr. terorizem, širjenje orožja za množično uničevanje, notranji in regionalni konflikti itd.), zagotavljanje civilne varnosti in zaščite prebivalstva pred različnimi vrstami tveganj (npr. naravne katastrofe, organiziran kriminal, zdravstvene in okoljske krize) (European Comission, 2004a).

\subsection{Pregled strukture izdatkov prihodnje finančne perspektive EU}

Obstoječa klasifikacija tekoče finančne perspektive 2000-2006, ki temelji na sedmih glavnih izdatkovnih postavkah, se je izkazala za razmeroma togo, saj ne omogoča ustreznega prilagajanja ter učinkovite uporabe razpoložljivih sredstev za dosego zastavljenih ciljev razširjene EU. Zato prihodnja finančna perspektiva EU predvideva zmanjšanje števila glavnih izdatkovnih postavk na pet, usklajenih s predhodno predstavljenimi temeljnimi prioritetami razširjene EU (glej razpredelnico 1). Sicer lahko od posameznih držav članic pričakujemo nasprotovanja glede zmanjšanega števila postavk, saj to povečuje nepreglednost finančne perspektive, 


\section{Aleksander Aristovnik \\ Oblikovanje finančne perspektive EU in pogajalska izhodišča Slovenije}

vendar se verjetno število postavk ne bo spremenilo. Hkrati Evropska komisija s ciljem povečanja prožnosti finančnega okvira predlaga uvedbo sistema prožnosti prerazporeditve (angl. reallocation flexibility) in ustanovitev Sklada za prilagajanje rasti (angl. Growth adjustment fund) ${ }^{2}$.

Razpredelnica 1: Predlog nove finančne perspektive 2007-2013 (v mio. evrov; v cenah leta 2004)

\begin{tabular}{|c|c|c|c|c|c|c|c|c|}
\hline $\begin{array}{l}\text { Odobritve za } \\
\text { prevzem obveznosti }\end{array}$ & $2006^{11}$ & 2007 & 2008 & 2009 & 2010 & 2011 & 2012 & 2013 \\
\hline 1. Trajnostna rast & 46.621 & 58.735 & 61.875 & 64.895 & 67.350 & 69.795 & 72.865 & 75.9 \\
\hline $\begin{array}{l}\text { 1a. Konkurenčnost za } \\
\text { rast in zaposlenost }\end{array}$ & 8,791 & 12.105 & 14.390 & 16.680 & 18.965 & 21.250 & 23.540 & 25.825 \\
\hline $\begin{array}{l}\text { 1b. Kohezija za } \\
\text { rast in zaposlenost }\end{array}$ & 37.830 & 46.630 & 47.485 & 48.215 & 48.385 & 48.545 & 49.325 & 50.125 \\
\hline $\begin{array}{l}\text { 2. Varovanje in } \\
\text { upravljanje z naravnimi viri }\end{array}$ & 56.015 & 57.180 & 57.900 & 58.115 & 57.980 & 57.850 & 57.825 & 57.805 \\
\hline - za kmetijstvo & 43.735 & 43.500 & 43.673 & 43.354 & 43.034 & 42.714 & 42.506 & 42.293 \\
\hline $\begin{array}{l}\text { 3. Državljanstvo, svoboda, } \\
\text { varnost in pravičnost }\end{array}$ & 2.342 & 2.570 & 2.935 & 3.235 & 3.530 & 3.835 & 4.145 & 4.455 \\
\hline 4. EU-globalni partner ${ }^{3)}$ & 11.232 & 11.280 & 12.115 & 12.885 & 13.720 & 14.495 & 15.115 & 15.740 \\
\hline 5. Administrativni stroški & 3.436 & 3.675 & 3.815 & 3.950 & 4.090 & 4.225 & 4.365 & 4.500 \\
\hline $\begin{array}{l}\text { Skup } \\
\text { za pre }\end{array}$ & 120.688 & 133.560 & 138.700 & 143.140 & 146.670 & 150.200 & 154.315 & 158.450 \\
\hline $\begin{array}{l}\text { Odobrene obveznosti } \\
\text { (v \% BND) }\end{array}$ & 1,15 & 1,23 & 1,25 & 1,26 & 1,26 & 1,26 & 1,27 & 1,27 \\
\hline \begin{tabular}{|l|}
$\begin{array}{l}\text { Skupaj } \\
\text { (odobrena plačila) }{ }^{213} \text { 3) }\end{array}$ \\
\end{tabular} & 114.740 & 124.600 & 136.500 & 127.700 & 126.000 & 132.400 & 138.400 & 143.100 \\
\hline $\begin{array}{l}\begin{array}{l}\text { Odobrena plačila } \\
\text { ( } v \% \text { BND) }\end{array} \\
\end{array}$ & 1,09 & 1,15 & 1,23 & 1,12 & 1,08 & 1,11 & 1,14 & 1,15 \\
\hline Razpoložljiva razlika & 0,15 & 0,09 & 0,01 & 0,12 & 0,16 & 0,13 & 0,10 & 0,09 \\
\hline $\begin{array}{l}\text { Zgor } \\
\text { sreds }\end{array}$ & 1,24 & 1,24 & 1,24 & 1,24 & 1,24 & 1,24 & 1,24 & 1,2 \\
\hline
\end{tabular}

Opomba: "Izdatki za leto 2006 so del tekoče finančne perspektive 2000 - 2006 in so prirejeni novi nomenklaturi prihodnje finančne perspektive z namenom, da se omogoči primerjava med finančnima perspektivama. Izdatki v okviru postavke 3 in 4 vključujejo sredstva Solidarnostnega sklada (961 milijonov evrov; v cenah leta 2004) in ERS (ocenjeno na 3 milijarde evrov).

${ }^{21}$ Od leta 2006 vključuje izdatke Solidarnostnega sklada (ocenjeno na 1 milijardo evrov; v cenah leta 2004). zračunana odobrena plačila vključujejo izdatke sklada od leta 2007.

${ }^{31}$ Vključitev ERS v proračun EU je predvidena za leto 2008, zato odobrena plačila za sklad pred tem letom niso vključena. Zaradi možnosti primerjav se upoštevajo odobritve za prevzem obveznosti ERS tudi pred letom 2008.

Vir: European Commission, 2004d.

2 Sklad naj bi bil vključen v izdatkovno postavko trajnostne rasti in bi omogočal prilagajanje proračunskih izdatkov $v$ smeri hitrejšega odzivanja na spremembe v okolju s ciljem zagotavljanja trajnostnega gospodarskega in socialnega razvoja EU. Predvidena sredstva sklada so do ene milijarde evrov letno, ki pa bodo lahko dopolnjena z dodatnimi neizkoriščenimi sredstvi strukturnih skladov EU (ESRR in ESS) (Council of the European Union, 2004). 


\section{Aleksander Aristovnik \\ Oblikovanje finančne perspektive EU in pogajalska izhodišča Slovenije}

Struktura sredstev $\vee$ okviru nove finančne perspektive kaže, da bo leto pred začetkom obdobja (2007-2013) za cilje lizbonske strategije namenjenih 0,08 odstotka bruto nacionalnega dohodka (BND) EU, ki pa bodo $\vee$ obdobju prihodnje finančne perspektive narasli na 0,21 odstotka BND (glej sliko 1). Trikratnega povečanja bodo deležni tudi programi na področju državljanstva, svobode, varnosti in pravičnosti (na 0,03 odstotka BND). Tudi sredstva za potrebe kohezijske politike bodo rahlo narasla, in sicer za štiri stotinke strukturne točke, na 0,41 odstotka BND. $\mathrm{Na}$ drugi strani se pričakuje znižanje razpoložljivih sredstev za varovanje in upravljanje z naravnimi viri (kmetijstvo predstavlja skoraj 75 odstotkov teh sredstev) v obdobju 2006-2013, in sicer z 0,53 odstotka na 0,46 odstotka BND. Nerealno sliko prikazuje minimalno povečanje administrativnih stroškov, kamor so uvrščene le pokojnine in administrativni stroški institucij EU. Preostali, večji del administrativnih stroškov, potrebnih za izvedbo posameznih politik EU, je namreč vključen $v$ druge izdatkovne postavke, kar povečuje nepreglednost predlagane finančne perspektive EU.

Slika 1: Delež odobrenih plačil po posameznih izdatkovnih postavkah finančne perspektive EU (v \% BND)

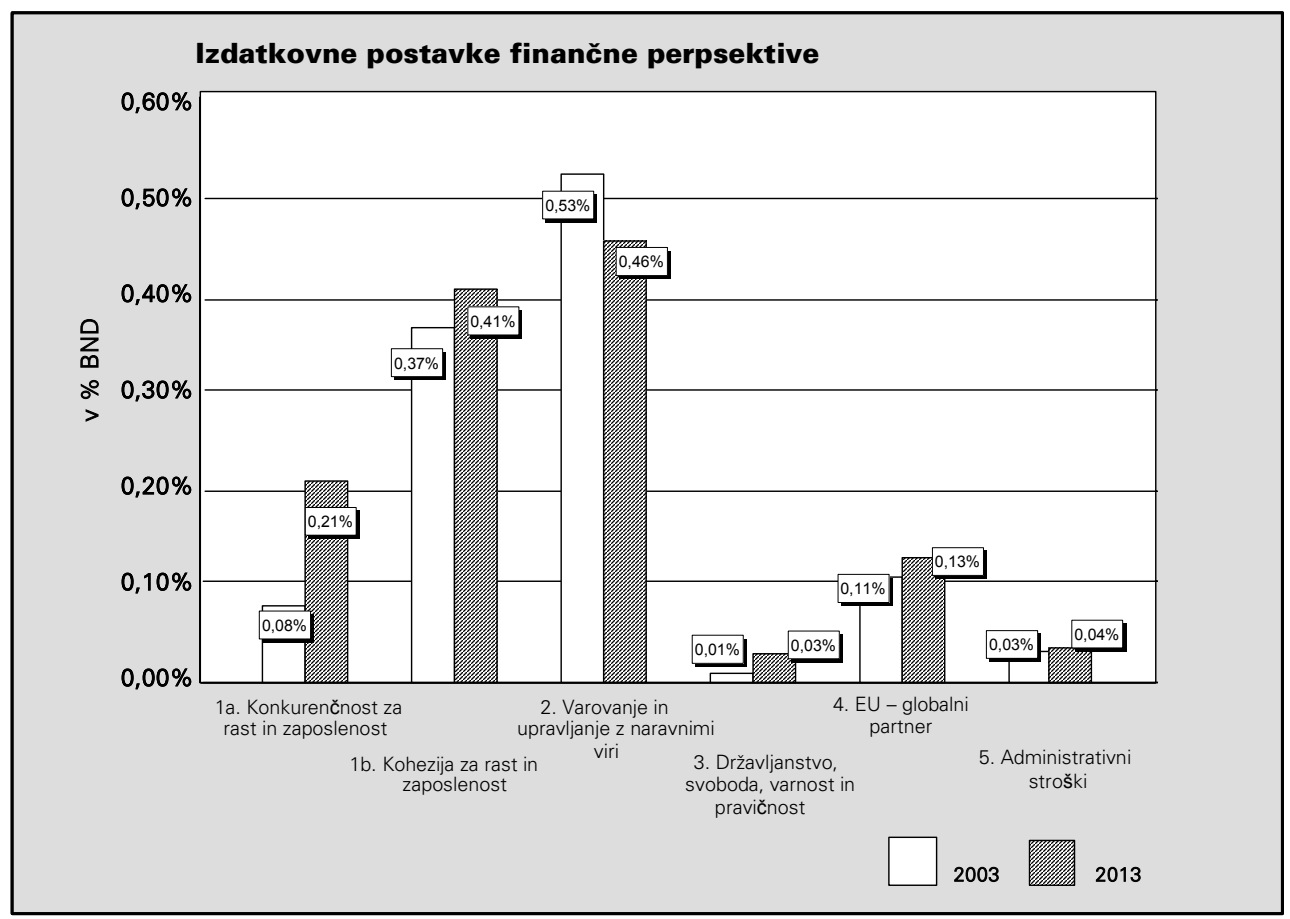

Vir: European Commission, 2004d; Iastni izračuni.

Sprememba strukture sredstev prihodnje finančne perspektive pa vendarle ne sledi $\vee$ celoti usmeritvam Sapirjevega poročila. Res je, da bo prišlo do realnega 


\section{Aleksander Aristovnik \\ Oblikovanje finančne perspektive EU in pogajalska izhodišča Slovenije}

zmanjšanja deleža izdatkov za kmetijstvo v celotnih odobrenih obveznostih, in sicer z ravni 33 odstotkov na raven 26 odstotkov v obdobju 2007-2013. Če upoštevamo tudi druge izdatke, povezane s programi na področju varovanja in upravljanja z naravnimi viri, ki naj bi financirali predvsem ukrepe za prestrukturiranje kmetijskega sektorja, bodo obravnavane odobrene obveznosti $v$ povprečju dosegale okoli 40 odstotkov celotnih odobrenih obveznosti v obdobju 2007-2013. To je sicer manj, kot predvideva tekoča finančna perspektiva (2000-2006) (v povprečju okoli 48 odstotkov), vendar še vedno znatno preveč, da bi na primer lahko dosegli večino ciljev lizbonske strategije.

Za razliko od predhodno predstavljene izdatkovne postavke ostale postavke beležijo realno povišanje odobrenih obveznosti. Tako se bodo odobrene obveznosti za področje državljanstva, svobode, varnosti in pravičnosti povišale realno za okoli 90 odstotkov in za potrebe EU kot globalnega partnerja za okoli 40 odstotkov v obdobju 2006-2013. Kljub bistvenemu povečanju predvidenih izdatkov za omenjeni postavki prihodnje finančne perspektive bo delež $v$ celotnih odobrenih izdatkih znašal le okoli 3 odstotke za postavko državljanstva in okoli 10 odstotkov za zunanjo politiko v letu 2013 (glej tudi sliko 1).

Slika 2: Delež izdatkov za kohezijo, namenjenih starim in novim članicam EU v obdobju 2006-2013 (v \% BND)

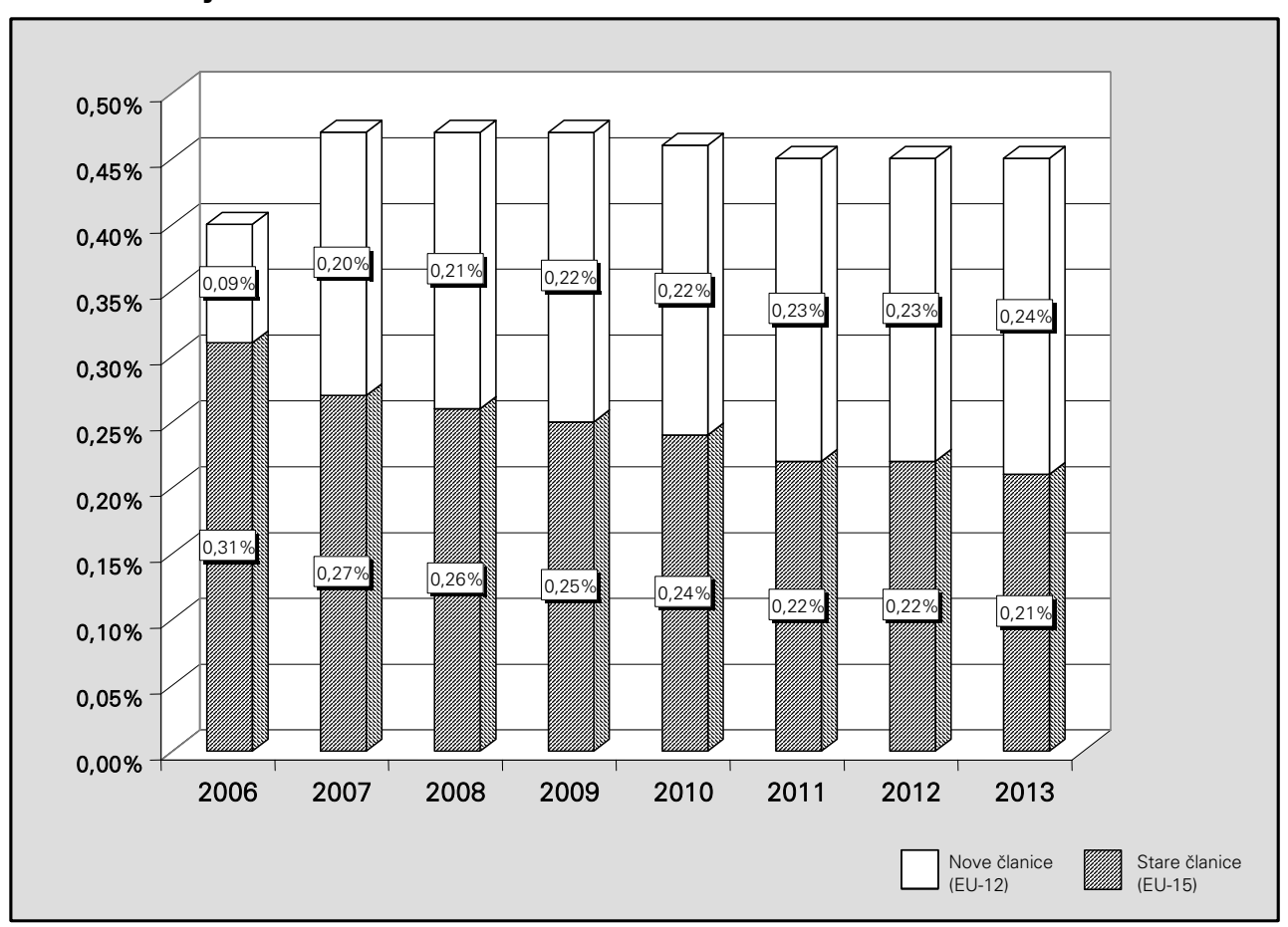

Vir: European Commission, 2004b. 


\section{Aleksander Aristovnik Oblikovanje finančne perspektive EU in pogajalska izhodišča Slovenije}

Zaradi širitve EU na vzhod, ki je občutno povečala razkorak med starimi in novimi državami članicami, ima kohezija pomembno mesto $v$ novi finančni perspektivi, saj predstavljala najpomembnejšo posamično kategorijo proračuna, na katero bi $\checkmark$ povprečju odpadlo dobrih 33 odstotkov vseh sredstev (kar je za več kot 4 odstotne točke več kot za kmetijstvo). Znotraj navedenih sredstev Evropska komisija ohranja in celo krepi načelo koncentracije, kar pomeni, da naj bi največja pozornost še vedno veljala manj razvitim regijam, s posebnim poudarkom na desetih (oz. dvanajstih) novih članicah, pri čemer naj bi se ohranilo pravilo najvišje zgornje pomoči državi v višini 4\% BDP (European Commission, 2004c). Predvsem zato bo sorazmerno spodbuden trend prerazporeditev sredstev po izdatkovnih postavkah (glej razpredelnico 1) spremljala tudi pospešena dinamika prelivanja sredstev od starih $k$ novim državam članicam EU. Medtem ko so bila sredstva za nove države članice za namene kmetijstva fiksno določena že na bruseljskem vrhu leta 2002, je za potrebe kohezijske politike EU predvideno znatno prelivanje sredstev $\vee$ prid novim državam članicam. Tako bodo imele nove države članice (vključno z Bolgarijo in Romunijo) leta 2007 na razpolago 42,6 odstotka vseh sredstev EU za potrebe kohezijske politike, leta 2013 pa že 53,3 odstotka (glej sliko 2). Takšna razporeditev sredstev je nujna, če želi EU v prihodnosti doseči postopno realno konvergenco med državami in regijami znotraj EU.

S ciljem zagotavljanja proračunske discipline je EU uvedla t. i. zgornjo mejo uporabe lastnih sredstev (angl. own resources ceiling), ki jo Svet EU določi soglasno in mora biti ratificirana tudi v vseh parlamentih držav članic. Temeljno vprašanje prihodnje finančne perspektive je oblikovanje "večjega ali "manjšega" proračuna EU. V obdobju tekoče finančne perspektive (2000-2006) je določeno, da je zgornja meja lastnih sredstev za prevzem obveznosti postavljena pri 1,31 odstotka BND EU oz. za odobrena plačila pri 1,24 odstotka (Schreyer, 2004). Kljub ambiciozno zastavljenim ciljem in spremenjenim okoliščinam (širitev EU, vključitev Evropskega razvojnega sklada $(E R S)^{\mathbf{3}}$ in Solidarnostnega sklada ${ }^{\mathbf{4}}$ ) Evropska komisija predlaga, predvsem zaradi pritiskov članic neto plačnic ${ }^{\mathbf{5}}$, ohranitev zgornje meje lastnih sredstev $\vee$ prihodnji finančni perspektivi (glej razpredelnico 2$)^{6}{ }^{6}$

3 Evropski razvojni sklad (ERS), ustanovljen že z Rimsko pogodbo (1957), je finančni instrument EU, ki ponuja finančno in tehnično pomoč afriškim, pacifiškim in tihomorskim državam ter čezmorskim državam in ozemljem.

4 Solidarnostni sklad EU je bil ustanovljen novembra 2002 s ciljem, da se lahko EU hitro, učinkovito in prožno odzove na nepričakovane okoliščine $v$ državah članicah in državah kandidatkah.

5 Tako je decembra 2003 šest držav neto plačnic (Avstrija, Francija, Nizozemska, Nemčija, Švedska in Velika Britanija) naslovilo pismo na Evropsko komisijo, v katerem predlagajo uvedbo zgornje meje odobrenih plačil v višini 1 odstotka BND (Financial Perspective 2007-2013, 2004)

$6 \mathrm{~V}$ novi finančni perspektivi je dejansko zgornja meja odobritev za prevzem obveznosti 1,26 odstotka BND. čeprav je izkazana zgornja meja za odobrena plačila 1,24 odstotka BND, ta ne upošteva izdatkov razvojne pomoči, ki naj bi bili del predlaganih odobritev za prevzem obveznosti in plačil v obdobju 20082013 (Mayhew, 2004). 


\section{Aleksander Aristovnik \\ Oblikovanje finančne perspektive EU in pogajalska izhodišča Slovenije}

Predhodno ugotovitev potrjuje tudi primerjava tekoče in predlagane prihodnje finančne perspektive, ki sicer pokaže, da je $v$ povprečju predvideno rahlo povišanje odobrenih plačil (z 1,10 odstotka na 1,14 odstotka BND) (glej razpredelnico 2). Vendar pa je treba $\vee$ omenjeni primerjavi upoštevati, da $\vee$ tekočem obdobju ERS in Solidarnostni sklad nista vključena $v$ finančno perspektivo, medtem ko bosta od leta 2008 postala del nove finančne perspektive. Tako je dejansko povišanje le 0,02 strukturne točke. Še več, če iz prihodnje finančne perspektive izključimo sredstva ERS in Solidarnostnega sklada ter sredstva, predvidena za Bolgarijo in Romunijo, potem je za prihodnjo finančno perspektivo predvidenih le 1,09 odstotka BND, kar je celo manj kot $v$ tekoči finančni perspektivi (1,10 odstotka).

Razpredelnica 2: Zgornja meja odobrenih plačil - primerjava obdobij 20002006 in 2007-2013 (v \% BND)

\begin{tabular}{|l|c|c|c|c|c|c|}
\hline & \multicolumn{3}{|c|}{$2000-2006$} & \multicolumn{3}{c|}{$2007-2013$} \\
\cline { 2 - 7 } & najnižja & povprečna & najvišja & najnižja & povprečna & najvišja \\
\hline $\begin{array}{l}\text { Lastna } \\
\text { sredstva }\end{array}$ & 1,24 & 1,24 & 1,24 & 1,24 & 1,24 & 1,24 \\
\hline $\begin{array}{l}\text { Finančna } \\
\text { perspektiva }\end{array}$ & $1,09^{1)}$ & $\begin{array}{c}1,10^{1)} \\
(1.12)\end{array}$ & $1,11^{11}$ & $1,08^{21}$ & $1,14^{21}$ & $1,23^{21}$ \\
\hline Proračun & 0,99 & 1,05 & 1,09 & - & - & - \\
\hline
\end{tabular}

Opomba: " upoštevana sprememba finančne perspektive v I. 2003 zaradi širitve (v oklepaju je vrednost, ki vključuje ERS in Solidarnostni sklad).

${ }^{2)}$ vključuje ERS in Solidarnostni sklad.

Vir: European Commission, 2004b.

$\checkmark$ povezavi z novo finančno perspektivo se izpostavljajo tudi druga pomembna vprašanja. Pri tem lahko izpostavimo predvsem vprašanja, povezana s sistemom financiranja, kot sta struktura lastnih sredstev in instrument popravka. Tako naj bi bil obstoječi sistem strukture lastnih sredstev preveč kompleksen in nejasen ter naj bi omejeval finančno samostojnost EU. Zato se znotraj EU pojavljajo različni predlogi o oblikovanju »novega " lastnega vira EU (t. i. evropski davek), in sicer v obliki davka na dobiček pravnih oseb, "originalnega" davka na dodano vrednost (DDV) in energijskega davka. Evropski davek torej ne bi bil uveden popolnoma na novo, ampak bi se zbiral kot določen delež že obstoječih nacionalnih davkov (European Commission, 2004b). Evropska komisija sicer najbolj zagovarja drugi predlog, po katerem bi lastne vire EU predstavljal določen del DDV $\vee$ državah članicah, vendar se je izkazalo, da predlog zaenkrat nima zadostne podpore med državami članicami EU. Sicer pa bi sama uvedba evropskega davka omogočila zmanjšanje prispevkov držav članic na osnovi BND, ne da bi bil ogrožen njihov javnofinančni položaj.

Problematično področje ostaja tudi že obstoječi instrument popravka (t. i. britanski rabat), ki naj bi zmanjševal prevelika neravnovesja $\vee$ neto plačilih posameznih 


\section{Aleksander Aristovnik \\ Oblikovanje finančne perspektive EU in pogajalska izhodišča Slovenije}

držav članic EU. Gre za instrument, ki ga je EU leta 1984 uvedla zaradi Velike Britanije, vendar po mnenju večine članic ni pravičen in bi ga bilo treba preoblikovati v t. i. splošen instrument popravka (angl. generalized correction mechanism). Predlagani instrument, ki naj bi začel veljati leta 2008, naj bi se aktiviral v primeru, ko neto plačnica države preseže mejo 0,35 odstotka njenega BND. $V$ tem primeru bi se državi članici vrnilo dve tretjini presežka, pri čemer bi bila povračila omejena na 7,5 milijarde evrov na letni ravni (European Commission, 2004e).

\section{Slovenija in finančna perspektiva EU 2007-2013}

Če želi Slovenija pospešiti gospodarsko rast in čim hitreje doseči povprečno stopnjo razvitosti EU, bo ta cilj tesno povezan z rezultati pogajanj o novi finančni perspektivi za obdobje 2007-2013. Eden glavnih ciljev Slovenije $v$ okviru teh pogajanj je zagotovitev približno enakega obsega sredstev EU, kot ga bodo deležne druge podobno razvite države EU. Na ta način bodo zagotovljena nujno potrebna potencialna sredstva za povečan obseg naložb $v$ gospodarstvu. Vendar bo dejanski obseg naložb $\vee$ veliki meri odvisen od administrativne usposobljenosti države za črpanje sredstev EU, tako $v$ smislu priprave dovolj velikega števila kakovostnih programov in projektov, primerne institucionalne ureditve države, kakor tudi zadostnega obsega domačih javnih, predvsem pa zasebnih virov financiranja naložb.

Slovenija se je že septembra 2003 dejavno vključila v priprave za oblikovanje finančnega okvira EU za obdobje po letu 2006, ko je sprejela temeljne vsebinske usmeritve do naslednje finančne perspektive EU. Stališče Slovenije do predloga finančne perspektive, sprejetega februarja 2004, je pozitivno, saj le-ta predstavlja dobro podlago za pogajanja (Prednostne naloge Slovenije za delo v svetu Evropske unije $v$ letu 2004, 2004). Slovenija pozitivno sprejema tudi prvi sveženj finančnih in zakonodajnih predlogov, vezanih na naslednjo finančno perspektivo, ki jih je sprejela Evropska komisija julija 2004. V nadaljevanju si najprej oglejmo stališča Slovenije po posameznih prioritetah nove finančne perspektive EU, kasneje pa tudi njene usmeritve glede pomembnejših odprtih vprašanj prihodnje finančne perspektive.

I) Trajnostni razvoj - spodbujanje rasti, kohezije in zaposlenosti

$\checkmark$ povezavi s področjem trajnostnega razvoja Slovenija podpira stališče Evropske komisije glede prestrukturiranja sredstev SKP $\vee$ smeri soočanja z novimi izzivi, povezanimi s pridelavo zdrave hrane, zaščito zdravja ljudi in razvoja podeželja. Za Slovenijo, ki ima neugodno posestno in parcelno kmetijsko strukturo ter izjemno visok delež površin na območjih z omejenimi možnostmi kmetovanja, je takšno prestrukturiranje izjemnega pomena za ohranjanje kmetijske predelave. Gre torej za logično nadaljevanje in nadgrajevanje slovenskega pogleda na problematiko 


\section{Aleksander Aristovnik Oblikovanje finančne perspektive EU in pogajalska izhodišča Slovenije}

razvoja podeželja, saj je Slovenija dajala tej problematiki izreden pomen $v$ vseh strateških in programskih dokumentih v zadnjem desetletju.

Za Slovenijo je ugoden tudi predlog finančne perspektive na področju kohezijske politike. Sicer je Slovenija že v obdobju 2001-2003 dosegla 76 \% povprečnega $\mathrm{BDP}$ na prebivalca razširjene $\mathrm{EU}$ in $\mathrm{s}$ tem za eno odstotno točko presegla prag ustreznosti za najbogatejši kohezijski cilj, tj. konvergenco in konkurenčnost. Z nadaljnjo širitvijo leta 2007 (Bolgarija in Romunija) se bo položaj Slovenije v smislu upravičenosti do sredstev strukturnih skladov še dodatno poslabšal. Zato Slovenija zagovarja in podpira stališče Evropske komisije, da bi morala imeti geografska območja, ki bodo izgubila status upravičenosti zaradi same razširitve EU (t. i. statistični učinek), dostop do večjega obsega finančnih sredstev EU za strukturne namene kot tista območja, ki so status upravičenosti izgubila zaradi dosežene stopnje svoje gospodarske razvitosti. Tu lahko Slovenija pričakuje podporo tudi nekaterih starih članic EU, ki so se znašle v podobnem položaju (npr. Španija, Grčija in Portugalska).

Eno izmed pomembnih pogajalskih izhodišč na področju kohezijskih sredstev bi za Slovenijo pomenile tudi novoustanovljene pokrajine, ki bi omogočile zmanjšanje negotovosti glede prihodnjega neto finančnega položaja Slovenije. Medtem ko je na ravni NUTS 1 (tako imenovana evropska klasifikacija teritorialnih enot) jasno, da bo Slovenija opredeljena kot ena regija, je vprašljiva nadaljnja delitev Slovenije. ${ }^{\mathbf{8}}$ Predvsem si je pomembno zagotoviti primerno ozemeljsko razdelitev na ravni NUTS 2, saj je za to raven v prihodnji finančni perspektivi namenjenih kar 78,5 odstotka kohezijskih sredstev.

\section{II) Evropski model družbe - svoboda, varnost in pravičnost}

Podobno kot za vse druge države članice je tudi v interesu Slovenije, da postane EU prostor svobode, varnosti in pravičnosti. Evropska komisija predlaga, da EU še naprej namenja veliko pozornost krepitvi varnosti znotraj EU in $v$ okviru tega ukrepanju proti terorizmu, čim boljšemu upravljanju z zunanjo mejo EU in izboljšanju operativnega sodelovanja med policijo, carino in varnostnimi službami. Ker je Slovenija z vstopom v EU postala, tako kot vse nove države članice (razen češke), njena mejna članica, je toliko večja pozornost Slovenije usmerjena nadzoru zunanje meje in drugim problemom, povezanim z obravnavanim področjem (azil in priseljevanje, preprečevanje kriminala, policijsko in pravosodno sodelovanje itd.) Zato je $\vee$ interesu

7 Zadnji predlog, ki ima širšo podporo z vidika gospodarskega, geografskega, prebivalstvenega in funkcijskega merila, predvideva členitev Slovenije na osem pokrajin (predlagana pokrajinska središča so Celje, Koper, Kranj, Ljubljana, Maribor, Murska Sobota, Nova Gorica in Novo mesto) (Poročilo o uresničevanju izhodišč za nadaljnji razvoj lokalne samouprave v republiki Sloveniji, 2004).

8 Obstajajo določeni pogoji za ustanovitev regij na različnih ravneh, ki so bili leta 2003 formalizirani v obliki uredbe EU (št. 1059/2003), kjer je natančno določena omejitev velikosti regij NUTS na različnih ravneh. Na primer, za regije na ravni NUTS 2 se zahteva najmanj 800 tisoč in največ tri milijone prebivalcev. Po tej opredelitvi je lahko Slovenija razdeljena na dve ali ob dokazanih geografskih, zgodovinskih, kulturnih in drugih pomembnih okoliščinah na tri kohezijske regije. 


\section{Aleksander Aristovnik \\ Oblikovanje finančne perspektive EU in pogajalska izhodišča Slovenije}

Slovenije povečanje sredstev, namenjenih krepitvi vloge EU kot prostoru svobode, varnosti in pravičnosti. $\vee$ pogajanjih si bo Slovenija kot mejna članica EU posebej prizadevala, da se primerna sredstva predvidijo za varovanje skupne zunanje meje EU, saj obstoječi predlog ne omogoča doseganja zastavljenih ciljev na tem področju. ${ }^{9}$ Pri tem lahko Slovenija računa na podporo vseh novih kakor tudi nekaterih starih članic EU (npr. Italije).

\section{III) Krepitev vloge EU v svetu}

Slovenija je kot polnopravna članica EU pridobila pravico tudi do sooblikovanja zunanje in varnostne politike EU. Pri tem bo še posebej zainteresirana za sooblikovanje politike do Zahodnega Balkana, kjer ima Slovenija vitalen interes za stabilnost regije tako $v$ varnostnem, političnem kot gospodarskem pogledu. Zato morajo biti prizadevanja Slovenije usmerjena $\vee$ usklajevanje časovnih okvirov za približevanje Zahodnega Balkana EU, kljub določenim zadržkom glede nadaljnje širitve znotraj EU.

Glede na to, da v predlogu finančne perspektive ni posebej izpostavljena izdatkovna postavka, ki bi pokrivala širitev, ampak je kot globalni partner vključena $v$ okvir področja EU, to nakazuje na verjetno upočasnitev širitve EU, kar ni v interesu Slovenije. $V$ nasprotju s tem ima veliko podporo Slovenije oblikovanje Instrumenta evropske soseščine (angl. European Neighborhood Instrument) ${ }^{\mathbf{1 0}}$ in enotnega Predpristopnega instrumenta (angl. Pre-accession Instrument), ki naj bi nadomestil obstoječe predpristopne instrumente (Phare, ISPA in Sapard), s ciljem povečanja njihove učinkovitosti in uspešnosti. Vsekakor je nadaljnja širitev EU na jugovzhodni del Evrope $v$ slovenskem interesu, zato je podpora Slovenije vsebinskemu cilju širitve EU in za te namene predvidenemu znesku izdatkov $v$ naslednji finančni perspektivi samoumevna.

Glede na zgoraj predstavljena stališča po posameznih prioritetah Slovenija zagovarja finančni predlog, po katerem bi finančna perspektiva $\vee$ sedemletnem obdobju v povprečju dosegla 1,14 BND odobrenih sredstev za plačila. Treba pa je izpostaviti, da bi bilo verjetno z dolgoročnega vidika smiselno, da se Slovenija pridruži šesterici držav neto plačnic, ki vneto zagovarjajo zgornjo mejo izdatkov $\vee$ višini 1

9 Slovenija bo v obdobju 2004-2006 prejela 107 milijonov evrov pomoči, namenjenih za vzpostavitve in vzdrževanja schengenske meje, kar predstavlja okoli 45 odstotkov celotnih stroškov (Ministrstvo za finance, 2003). Hkrati Slovenija upravičeno pričakuje ohranitev finančnih sredstev za te namene tudi $\vee$ obdobju naslednje finančne perspektive, saj imajo od učinkovitega in uspešnega delovanja schengenske meje korist vse države članice EU.

10 Instrument Evropske soseščine, eden izmed šestih instrumentov prioritete EU kot globalnega partnerja, naj bi nadgradil že obstoječe t. i. "Sosedske programe« s ciljem okrepitve stabilnosti, varnosti in blaginje EU kakor tudi sosednjih držav. Na ta način bi se preprečila delitev med EU in njenimi sosedskimi državami, saj bi EU slednjim ponudila možnost sodelovanja v različnih političnih, varnostnih, gospodarskih in kulturnih aktivnostih EU (European Commission, 2004f). 


\section{Aleksander Aristovnik \\ Oblikovanje finančne perspektive EU in pogajalska izhodišča Slovenije}

odstotka BND. Vendar zaradi nepripravljenosti posameznih držav članic (predvsem Francije in španije) za znatnejše zmanjšanje izdatkov za kmetijstvo $v$ proračunu EU Slovenija zagovarja obstoječi predlog Evropske komisije.

Kar zadeva financiranje obravnavane finančne perspektive, se Slovenija zavzema za takšno spremembo sistema financiranja proračuna EU, po kateri bodo njegove prihodke sestavljali tradicionalni lastni viri in viri na osnovi BND, ob postopnem opuščanju vira na osnovi DDV. Hkrati je stališče Slovenije, da zaradi nezadostne stopnje davčne harmonizacije znotraj EU in zahtevnega administriranja evropski davek ni primeren finančni vir za proračun EU. V kontekstu iskanja celovite rešitve za naslednjo finančno perspektivo Slovenija podpira tudi predlog za odpravo instrumenta popravka proračunskega neravnovesja $\vee$ korist posameznih držav članic. Sicer bi bila za Slovenijo najboljša rešitev odprava kakršnegakoli instrumenta popravka, vendar pa je nov predlog Evropske komisije za Slovenijo finančno ugodnejši kot ohranitev obstoječega sistema. ${ }^{11}$

Pri pogajanjih o naslednji finančni perspektivi bo Slovenija, med drugim zaradi potrebe po izpolnjevanju strogih pravil Pakta stabilnosti in rasti ${ }^{\mathbf{1 2}}$, upoštevala tudi potencialne negativne fiskalne učinke, ki bi bili posledica (ne)izpolnjevanja pogojev za črpanje povečanega obsega evropskih sredstev. V času, ko je Slovenija V "čakalnici« za evro (v ERM II), bi lahko takšni negativni učinki ogrozili načrtovani prevzem evra $v$ letu 2007. $\vee$ povezavi s tem bi se morala Slovenija tudi zavzemati za reformo Pakta in za večje osredotočenje skupnih pravil na kakovost in vzdržnost javnih financ posameznih držav. Znano je namreč, da obstoječa fiskalna pravila, ki povzročajo veliko spora in nesoglasja znotraj EU, preprečujejo neodgovorno nacionalno fiskalno politiko, vendar hkrati prinašajo tudi veliko mero togosti.

Ker se Slovenija zaveda, da je pravočasni časovni načrt sprejemanja nove finančne perspektive ključnega pomena za neprekinjeno financiranje programov EU, je čimprejšnji dogovor o naslednji finančni perspektivi predpogoj za pravočasno prilagoditev programov EU $v$ skladu s potrebami naslednjega finančnega obdobja in nemoten sprejem proračuna EU za leto 2007. Skladno s tem Slovenija podpira

11 Po zadnjih izračunih naj bi Slovenija v obdobju 2008-2013 od EU brez kakršnegakoli instrumenta popravka prejemala neto plačila $\vee$ višini 1,4 odstotka bruto nacionalnega proizvoda (BNP). $V$ primeru ohranitve obstoječega sistema britanskega rabata se neto pritoki zmanjšajo na 1,31 odstotka BNP, medtem ko naj bi sprejem splošnega mehanizma popravka zmanjšal neto pritoke na 1,34 odstotka BNP v enakem obdobju (European Commission, 2004e).

12 Pakt je bil sprejet na zasedanju Evropskega sveta v Amsterdamu (1997) in natančneje določa pravila ekonomske koordinacije in pogoje, pod katerimi se uporablja postopek v zvezi s čezmernim primanjkljajem. Namen Pakta je zagotoviti disciplino držav članic pri upravljanju javnih financ, saj vsebuje zavezo držav članic, da bodo spoštovale srednjeročni cilj glede proračuna, tj., da imajo izravnan proračun ali proračunski presežek (Resolution of the European Council on the Stability and Growth Pact, 1997). 


\section{Aleksander Aristovnik \\ Oblikovanje finančne perspektive EU in pogajalska izhodišča Slovenije}

stališče Evropske komisije, ki zagovarja zaključek pogajanj in sprejetje nove finančne perspektive najkasneje do sredine leta 2005.

\section{Zaključek}

Naslednja finančna perspektiva Evropske unije (EU), že četrta po vrsti, bo pomenila temeljni okvir evropskih politik v obdobju 2007-2013. Na ta način bo odločilno okvirjen prihodnji razvoj tako EU kakor tudi posameznih držav članic. Zato je toliko bolj pomembno, da se države članice dobro pripravijo na pogajanja in zaščitijo tako lastne interese kakor tudi interese EU kot celote. V ospredju pogajanj o naslednji finančni perspektivi bo zagotovitev njene enostavnosti, preglednosti, prožnosti, pravičnosti in razvojne naravnanosti, posamezna država članica pa si bo poleg teh ciljev želela zagotoviti tudi čim boljši neto finančni položaj.

Slovenija bo kot polnopravna članica prvič imela priložnost sodelovati pri oblikovanju naslednje finančne perspektive EU. To je še toliko bolj pomembno, ker je od vsebine naslednje finančne perspektive in od uspešnosti pogajanj $\vee$ veliki meri odvisen neto finančni pritok sredstev Sloveniji v obdobju, ko bo Slovenija verjetno zadnjič uvrščena $\vee$ skupino držav neto plačnic. Tudi zato je za Slovenijo ključnega pomena, da se ustrezno opredeli do vsebinskih in finančnih vprašanj ter da oblikuje različne koalicije s preostalimi državami članicami, s pomočjo katerih bo laže dosegala skupno zastavljene cilje pri pogajanjih.

$\checkmark$ okviru predlagane finančne perspektive EU Slovenija podpira prestrukturiranje sredstev za kmetijstvo v smeri predelave zdrave prehrane, zaščite zdravja ljudi kot tudi razvoja podeželja. Podpira tudi uresničevanje načela solidarnosti, ki naj bi se uresničevalo s preoblikovano kohezijsko politiko. Izgraditev EU kot prostora svobode, varnosti in pravičnosti ter povečanje vloge EU v svetu se ujamejo z usmeritvami Slovenije. Zato si bo Slovenija prizadevala za povečanje sredstev EU za te namene, še posebej na področjih varovanja skupne zunanje meje EU in nadaljnje širitve EU proti Zahodnemu Balkanu. Sloveniji se zdi primerna tudi predlagana zgornja meja sredstev lastnih sredstev za plačila v višini 1,24 odstotka BND in povprečna višina odobrenih plačil v višini 1,14 odstotka BND. Na strani finančnih virov pa Slovenija zagovarja postopno opuščanje vira na osnovi DDV ter zaenkrat nasprotuje uvedbi t. i. evropskega davka.

Ker je velika večina usmeritev Slovenije do nove finančne perspektive EU skladnih z usmeritvami Evropske komisije, bodo postavljeni cilji v okviru pogajanj zagotovo laže dosegljivi. To potrjujejo tudi izkušnje preteklih finančnih perspektiv, kjer so bili predlogi Evropske komisije največkrat v skoraj nespremenjeni obliki na koncu tudi potrjeni. Skladno s tradicijo težavnosti pogajanj pa je tudi pričakovati, da se bodo pogajanja o vsebini in obsegu prihodnje finančne perspektive zavlekla globoko v leto 2005 ali celo dlje. 


\section{Aleksander Aristovnik \\ Oblikovanje finančne perspektive EU in pogajalska izhodišča Slovenije}

Aleksander Aristovnik je magister ekonomskih znanosti, zaposlen na Fakulteti za upravo kot asistent za področji Temelji ekonomije in Ekonomika javnega sektorja s proračunskim financiranjem. V svojem raziskovalnem delu se ukvarja s področjem makroekonomije, mednarodne ekonomije in procesom integracije EU.

\section{Literatura in viri}

- $\quad$ Council of the European Union (2004): Financial Perspective for 2007 -2013: Analytical Report, Brussels, 2004

- European Commission (2004a): Communication from the Commission to the Council and the European Parliament: Building our common Future: Policy challenges and Budgetary means of the Enlarged Union 2007-2013. Brussel.

- $\quad$ European Commission (2004b): DG Budget, marec/april 2004.

- European Commission (2004c): Third Cohesion Report, Office for Official Publications of the European Communities, Luxembourg.

- European Commission (2004d): Proposal for renewal of the Interinstitutional agreement on budgetary discipline and improvement of the budgetary procedure. Commission Working Paper. Brussels.

- European Commission (2004e): Preventing Excessive Budgetary Imbalances in the EU. Dostopno: http://europa.eu.int/rapid/pressReleasesAction.do?reference=IP/04/908\&format=HTML\&age $\mathrm{d}=0$ \&language $=E N \&$ guilanguage $=$ en. 26.11.2004

- European Commission (2004f): Communication from the Commission: Paving the way for New Neighborhood Instrument. Brussels

- EU Regional policy (online) (2004). http://europa.eu.int/comm/regional_policy. 20.11.2004.

- Financial Perspective 2007-2013 (2004). http://www.euractiv.com/Article?tcmuri=tcm:29130497-16\&type=LinksDossier. 22.11.2004

- Mayhew, A. (2004): The Financial Framework of the European Union, 2007-2013: New Policies? New Money? Working paper, Sussex European Institute.

- Osnutek proračunskega memoranduma za leti 2004 in 2005 (2003). Ministrstvo za finance (2003), Ljubljana.

- Prednostne naloge Slovenije za delo v svetu Evropske unije v letu 2004 (2004). Vlada RS, Ljubljana.

- Poročilo o uresničevanju izhodišč za nadaljnji razvoj lokalne samouprave v republiki Sloveniji (2004), Vlada RS, Ljubljana.

- Resolution of the European Council on the Stability and Growth Pact (1997), Amsterdam, Official Journal C 236 of 02.08.1997. 
- Sapir, A. et al. (2003), An Agenda for a Growing Europe: Making the EU System Deliver, Report of an Independent High Level Group established at the initiative of the President of the European Commission (other members of the group: Philippe Aghion, Giuseppe Bertola, Martin Hellwig, Jean Pisani-Ferry, Dariusz Rosati, José Viñals and Helen Wallace), Brussels.

- $\quad$ Schreyer M. (2004): Financial Perspective 2007 - 2013, ECOFIN, Brussels. 
Aleksander Aristovnik

Oblikovanje finančne perspektive EU in pogajalska izhodišča Slovenije

\section{SUMMARY \\ Creation of EU Financial Perspective and the Slovenian Negotiating Positions}

In February 2004, the European Commission adopted a Communication setting out a policy programme for the new 2007-2013 financial perspective. It identifies three main political priorities of the enlarged EU: sustainable development, growth, cohesion and employment (i.e. the Lisbon agenda); completion of the areas of freedom, justice and security; and strengthening of the EU voice as a global partner. However, while this ambitious agenda requires significant financial sources, the Commission argues that the current ceiling, even for the EU-27, can remain at the current level of 1.24 percent of the EU Gross National Income (GNI). Eventually, by shifting the balance of current resources to new spending priorities the total amount over the whole period would amount to an average of 1.14 percent of GNI per year. Any lower level of this would make it difficult for the EU to meet its future obligations regarding the set goals.

Moreover, in July 2004 the Commission adopted the first set of detailed proposals on expenditure for the new financial period. These were accompanied by a Communication explaining the meaning of the proposals and seting out a new, simplified structure for the instruments under individual headings. Thus, the new structure of the financial perspective foresees a reduction in the expenditure headings from the current seven to five, which makes the financial perspective less transparent. Indeed, it will be much more difficult to identify spending on individual EU policies as well as on the administration. Moreover, in order to improve budget flexibility the Commission is proposing several flexibility mechanisms such as the establishment of flexible funds (i.e. Growth Adjustment Fund and the Solidarity Fund) and the adoption of a 'reallocation facility' system.

To some extent the Commission proposals have been inspired by the 'Sapir Report' which places improving competitiveness at the top of its policy objectives. Consequently, the Commission's financial perspective proposals suggest that agricultural spending be smaller in the future than in the past. In fact, in the course of time, agricultural spending is supposed to fall by 29 percent of total expenditure (commitments) and, by 2013, it will only be around 26 percent of the annual budget compared to the around 45 percent in today's financial perspective. On the other hand, cohesion expenditures are expected to grow substantially with time (by around 33 percent in real terms). 


\section{Aleksander Aristovnik \\ Oblikovanje finančne perspektive EU in pogajalska izhodišča Slovenije}

An even more significant increase is proposed for the competitiveness heading, which would then consume some 16 percent of total commitments by 2013 (only 9 percent in 2007), which is in line with the Lisbon agenda. The remaining headings, citizenship and the EU as a global partner, receive a large spending boost in real terms but, as a proportion of total spending, it remains quite low at 3 percent and 10 percent, respectively, of total commitments in 2013.

While most of the discussion concerns the expenditure side of the next financial perspective, the Commission raises two items on the own-resource side. The first considers the creation of a real own resource of the EU rather than the current system which relies on transfers authorised by the governments of member-states. However, given the state of relations between some of the member-states and the EU, this novelty is currently inappropriate. The second is the question of the British budget compensation (rebate), which is proposed to be replaced by a generalised rebate mechanism. The mechanism would compensate any member-state whose net contribution exceeded a certain threshold expressed as a percentage of its GNI. Nevertheless, there is a sharp divergence among member-states on the subject because a new generalised system of rebate could leave some member-states worse off than they are now.

The key objective of the new members, including Slovenia, must be economic growth and the process of catching up with the average development level in the EU. Therefore, it is in Slovenia's interest to restrict its payments to own resources in the EU budget as far as possible. Accordingly, as one of the more advanced economies among the new members Slovenia has a special interest in remaining a net beneficiary at least for the next financial period. Hence, Slovenia supports the idea that the own-resource limiting commitment appropriations and average payments appropriation amount to 1.24 and 1.14 percent of GNI, respectively. In addition, Slovenia supports restructuring of the EU budget in the direction suggested by the Sapir Report. Moreover, as an external border member-state Slovenia would like to see an increase in finance for protection of the EU external frontier. In addition, further EU enlargement towards Southeast Europe is another of Slovenia's vital interests. As far as the own-resource side of the budget is concerned, Slovenia supports the adoption of a generalised rebate mechanism and opposes any new real own resources of the EU. In line with that, Slovenia would remain a net beneficiary member-state by receiving 1.34 percent of Gross National Product (GNP). Finally, Slovenia strongly supports flexibility within the financial 


\section{Aleksander Aristovnik \\ Oblikovanje finančne perspektive EU in pogajalska izhodišča Slovenije}

framework as the EU increases its involvement in foreign affairs and meets new challenges of internal security and perhaps economic instability.

To conclude, the Slovenian positions support most of the proposals for the next financial perspective presented by Commission. Consequently, in order to allow sufficient time for preparing new programmes to implement the different policies Slovenia strongly supports calls that the financial perspective should be adopted by June 2005. Nevertheless, according to experience it is more likely that the negotiating process will be prolonged far into 2005 or even 2006. 